\title{
SURVEYS FOR POTENTIAL BIOCONTROL AGENTS FOR MOTH PLANT IN NEW ZEALAND AND ARGENTINA
}

\author{
N.W. WAIPARA ${ }^{1}$, C.J. WINKS ${ }^{1}$, A.F. GIANOTTI ${ }^{1}$, C.B. VILLAMIL ${ }^{2}$, \\ S.C. VILLAMIL ${ }^{2}$, R. DELHEY ${ }^{2}$, M. KIEHR ${ }^{2}$, M.G. TRAVERSA ${ }^{2}$ \\ and D.L. CARPINTERO ${ }^{3}$ \\ ${ }^{1}$ Landcare Research, Private Bag 92170, Auckland, New Zealand \\ ${ }^{2}$ Universidad Nacional del Sur, Bahia Blanca, Argentina \\ ${ }^{3}$ Natural History Museum of La Plata, La Plata, Argentina \\ Corresponding author: WaiparaN@landcareresearch.co.nz
}

\begin{abstract}
Moth plant, Araujia sericifera, is an environmental weed in northern regions of New Zealand. Due to its rapid spread, its ability to cause substantial damage to natural ecosystems and the increasing cost of conventional control methods, a biological control programme was initiated. A survey of the plant in New Zealand found that damage attributed to either disease or insect herbivory was minimal with little biocontrol potential. Botanical, pathogen and insect surveys were subsequently initiated in the native South American range to locate and identify potential agents for classical biocontrol. Potential agents associated with plant damage were collected. Damage was mostly due to pathogenic attack with $90 \%$ of moth plant populations showing disease symptoms. To date, eight fungal pathogens have been associated with plant die back, leaf necroses and a severe fruit rot. At least two mosaic (virus) diseases were also found, frequently associated with colonies of the aphid, Aphis nerii.

Keywords: environmental weeds, Araujia hortorum-sericifera complex, classical biological control, plant pathogens, Araujia mosaic virus, invertebrates.
\end{abstract}

\section{INTRODUCTION}

The identity and correct botanical name of moth plant (Family Apocynaceae) has been a matter of taxonomic controversy for some time and it has undergone numerous systematic transferences. In the current literature, it is generally known as either Araujia sericifera Brot. or as A. hortorum Fournier (Forster \& Bruyns 1992). In New Zealand it is currently named A. sericifera (Webb et al. 1988; Roy et al. 2004). The common name moth plant refers to the fact that insects, particularly moths and butterflies, can be trapped within the flowers. It is a fast-growing evergreen vine from South America that can scramble over trees and shrubs, completely smothering them. The choko-like fruit pods contain hundreds of wind-borne seeds that spread on fine silky parachutes.

Moth plant has the potential to be a serious invasive weed in all moist, mostly frost-free, areas of New Zealand, and to cause substantial environmental damage (Winks \& Fowler 2000; Esler 2004). Two assessments of weeds in Auckland and Northland each gave moth plant the highest ranking in terms of competitive ability and weed potential (Esler 1988, 2004; Craw 1999). It was introduced to New Zealand as a garden ornamental and first recorded as naturalised in 1888 (Webb et al. 1988). It has also naturalised in parts of Australia, Europe, North America and South Africa (Winks \& Fowler 2000).

Biological control has been identified as an appropriate control strategy for moth plant (Winks \& Fowler 2000), because in many of the areas being invaded, herbicide use would 
be likely to damage non-target species and the scale of the problem is such that manual control is often not feasible. Furthermore, prospects of finding suitably host-specific biocontrol agents are good because New Zealand has no native members in its sub family Asclepiadoideae. However, several introduced ornamental members of the Apocynaceae family are cultivated, such as Hoya spp. and swan plant, Gomphocarpus fruticosus.

This paper describes the results of two surveys. The first was to search for diseases or invertebrates exerting significant adverse impact on moth plant in New Zealand. The second was a botanical survey in South America, to determine the distribution and taxonomy of the plant in its native range along with initial surveys for potential candidates for classical biological control.

\section{MATERIALS AND METHODS}

\section{Survey of moth plant in New Zealand}

The invertebrate fauna and plant pathogens of moth plant were surveyed at $12 \mathrm{New}$ Zealand sites between October 2002 and March 2004. At each site, 10 collection locations were randomly selected. Methods outlined previously were used to collect invertebrates present on moth plant (Winks et al. 2004). A collecting tray $\left(80 \mathrm{~cm}^{2}\right)$ was placed under suitable parts of selected plants, and the foliage above the tray was hit five times with a solid stick. Invertebrates that fell onto the tray were collected with an aspirator for identification. Foliage, growing points, intact and cut stems were inspected for signs of invertebrates that were then collected for identification. A visual estimate was made of the amount of herbivore-related damage at each site. Plants at each collection point were also inspected for signs of pathogen damage. Other moth plant plants in the area were examined more superficially for obvious disease symptoms. Any diseased leaves, leaf petioles, stems, flowers, flower petioles, or pods found were collected for processing. A dissecting microscope was used to search necrotic areas for diagnostic reproductive structures of fungi. Methods outlined previously (Waipara et al. 2005) were used to isolate fungi from diseased tissues. Small pieces of tissue (174 in total) were cut from the leading edge of diseased areas and surface sterilised. The pieces were plated on potato dextrose agar (Difco Labs, Detroit, MI, USA) with $0.02 \%$ streptomycin (Sigma, St Louis, MI, USA), contained in 9-cm Petri dishes. Plates were incubated under nearultraviolet and white light ( $12 \mathrm{~h}$ photoperiod) at temperatures of $22 \pm 2{ }^{\circ} \mathrm{C}$ (day) and $18 \pm 2^{\circ} \mathrm{C}$ (night). Microcolonies that were initiated from tissue fragments were sub cultured for identification.

At Awhitu Regional Park, Auckland, a sample was collected from a diseased plant exhibiting symptoms consistent with viral infection. Symptoms were mosaic-like with chlorotic-yellowed, stunted, slightly distorted leaves (Waipara 2004). Diseased materials were excised and accessioned at the Biosecurity New Zealand, National Plant Pest Reference laboratory (NPPRL), Auckland, and processed to detect if plant virus was present (Waipara 2004).

\section{Survey of moth plant in South America}

A survey of the Araujia hortorum-sericifera complex in Argentina and Uruguay was initiated in 2004 and continued through the 2005 and 2006 growing seasons. Field trips were undertaken throughout most of the natural range of the complex to locate populations to study the plant's morphology and systematics. Plant samples from 137 Araujia populations were collected from the two different biogeographically defined regions of the native range. The northeastern, mainly subtropical, region of Argentina (provinces of Corrientes and Misiones, near the Brazilian border), and the Pampean temperate region, extending from the southern province of Santa Fe, to southern Buenos Aires province, on the Atlantic coast of Argentina and Uruguay. Referenced Araujia records from the following seven Argentinean herbaria, Facultad de Agronomía, Universidad Nacional de Buenos Aires (BAA), Instituto de Botánica del Nordeste (IBONE), Corrientes (CTES), Instituto Nacional de Tecnología Agropecuaria (INTA), Castelar (BAB), Departamento de Biología, Bioquímica y Farmacia, Universidad Nacional del Sur, Bahía Blanca (BBB), Facultad de Ciencias Agrarias, Universidad Nacional de Rosario, Rosario (UNR), were 
also used to help locate discreet populations across the native range. Herbaria specimens were revised and freshly collected plant materials were compared to determine the taxonomic identity of each Araujia population based on the morphological characteristics previously described for each species (Brotero 1817; Fournier 1885; Meyer 1944; Forster \& Bruyns 1992). Morphological comparisons were also made to the accepted New Zealand description for A. sericifera (Webb et al 1988).

Invertebrates and diseases associated with any plant damage were also collected (from 48 plant populations) for identification using the methods outlined for the New Zealand survey above.

\section{Survey of moth plant in New Zealand}

\section{RESULTS AND DISCUSSION}

No specialist moth plant feeding invertebrates were found in New Zealand, and any damage that could be attributed to invertebrate herbivory was minimal. Although over 100 species were collected and identified (Winks et al. 2004), the polyphagous sap-feeding passionvine hopper, Scolypopa australis, was the only abundant invertebrate found on moth plant during the survey. The oleander aphid, Aphis nerii, occasionally produced 'outbreaks' that led temporarily to very large populations but overall none of the herbivore niches on moth plant were well utilised in New Zealand.

Most disease symptoms observed were superficial, non-systemic, minor leaf spots that did not impact severely on the aggressive vegetative growth or flower/fruit/seed production. There were 119 culturable fungal isolates recovered from the 174 tissue pieces plated. Of the 119 fungal isolates, 113 were identified and the remaining 6 were sterile mycelium. All fungi were isolated from leaf disease symptoms, apart from Alternaria alternata, which was recorded from both leaf and stem disease. In total 16 fungal species were identified. Of these, only Colletotrichum gloeosporioides and Microsphaeropsis sp. are likely to be primary, yet still mild, pathogens of moth plant. The remaining 14 species were cosmopolitan, saprophytic or secondary pathogens, infecting the host after damage, insect feeding or infection by a primary pathogen, and therefore unlikely to be sufficiently virulent and/or host specific to be useful as biocontrol agents. Representative reference cultures were deposited in International Collection of Microorganisms from Plants, Landcare Research, Auckland, New Zealand.

The Awhitu sample exhibiting mosaic-like disease symptoms was infected by a transmissible agent (F. Ochoa-Corona, pers. comm.). However serological detection methods were unable to confirm the identity and type of the agent due to the symptomatic plant material containing very low titre levels of the infectious agent. Molecular PCR diagnostic methods, which can detect viral agents at low titre levels, could not be used, as to date no genetic sequences of Araujia mosaic virus have been deposited into the National Centre for Biotechnology Information's Genbank database (http://www.ncbi. nlm.nih.gov). Further work is required to identify the causal agent.

Given these results, both pathogen and invertebrate agents for biocontrol purposes will have to be sourced from the native South American range.

\section{Survey of moth plant in South America}

The important Araujia reference specimens held in Argentinean herbaria were revised. In all cases, plant material collected from the temperate Pampean region of Argentina and Uruguay, were identified as Araujia hortorum Fournier, as they matched the flower morphology (flowers with clearly patent corolla lobes) of the nomenclatural type material of this species. However, all the plants collected from the subtropical provinces of Misiones and Corrientes, in NE Argentina, showed the flower morphology (erect corolla lobes) matching the type and original description of A. sericifera Brot. Based on herbaria records and plant morphology, the populations currently named A. hortorum and $A$. sericifera appear to represent two different taxonomic entities. Despite what was proposed by Forster \& Bruyns (1992), it is likely that the morphological differences found between the two taxa may be sufficient to describe them as two separate species, as was proposed by Meyer (1944), or at least as two sub-specific entities within the same 
species. Based on the revised herbaria records and current plant collections obtained from Argentina, the identity of moth plant in New Zealand has been redetermined as belonging to the $A$. hortorum taxon. Further taxonomic and genetic studies are ongoing at Universidad Nacional del Sur and Landcare Research to validate this observation. Representative reference herbarium specimens from both taxonomic entities were prepared and deposited into the botanical herbarium collection of Universidad Nacional del Sur, Bahia Blanca, Argentina (BBB).

Approximately $90 \%$ of the 48 moth plant populations surveyed for damage during 2004-2005, were infected by several diseases that caused widespread leaf, stem, flower and occasional fruit damage. Within each population the incidence of diseased plants was also high and frequently there was more than one pathogen present. This high disease intensity may, in part, be due to the ruderal habit of the plant in its native range. Ten diseases were identified (Table 1). The most widespread fungal disease was a leaf spot caused by a species of Pseudocercospora. It caused angular yellow leaf lesions with black patches (due to sporulation) on the reverse of the leaf. Other necrotrophic pathogens were also collected from damaged plants (Table 1) and most were identified as Coelomycetous fungi. The leaf rust, Puccinia araujiae Lév., was also recovered in two different years from the same population at La Plata Argentina. In 2004, a small cluster of teliospores was observed on a few leaves, while in 2006, a severe outbreak was observed with $100 \%$ of plants infected and severely damaged by the disease. Two plant viruses, common Araujia mosaic virus and yellow mosaic virus (Alfalfa mosaic alfamovirus), were widespread throughout most of the plant's range and together with the Pseudocercospora and Ascochyta leaf spots, may exert a continuous pressure on the host population. Populations of Aphis nerii, a known vector of Araujia viruses (Waipara 2004), were frequently observed on plants exhibiting mosaic symptoms.

TABLE 1: Fungal and viral pathogens observed damaging Araujia sericiferahortorum in South American surveys during 2004-2005.

\begin{tabular}{|c|c|c|c|}
\hline Micro-organisms & $\begin{array}{l}\text { No. } \\
\text { collection } \\
\text { sites }\end{array}$ & Isolated $^{1}$ & Symptoms \\
\hline Ascochyta cf. araujae & 9 & yes & circular purple leaf-stem-fruit spots \\
\hline Colletotrichum cf. orbiculare & 1 & yes & leaf spots \\
\hline Oidium cf. insolitum & 1 & & powdery mildew \\
\hline Phoma-like & 1 & yes & small white leaf spot \\
\hline Pseudocercospora cf. fumosa & 17 & yes & yellow angular leaf spot \\
\hline Puccinia araujiae & 1 & & leaf rust \\
\hline Septoria cf. araujae & 1 & yes & leaf, stem, fruit rot \\
\hline Stagonospora-like & 1 & & white-necrotic leaf spots \\
\hline Araujia mosaic virus & 12 & & common mosaic \\
\hline Alfalfa mosaic Alfamovirus & 6 & & yellow mosaic \\
\hline
\end{tabular}

${ }^{1}$ Other fungi isolated, including Alternaria, Diplodia-like and Phomopsis, are possibly secondary invaders.

${ }^{2}$ Transferred to moth plant seedlings in the lab

Apart from the oleander aphid, the most widespread insect identified was a sap sucking bug, Oncopeltus stali (Lygaeidae), often observed swarming on the leaves, flowers and fruit. Work to identify the remaining 21 invertebrate species collected to date from moth plant in South America is ongoing. 


\section{CONCLUSION}

Despite moth plant being found free of its natural enemies in New Zealand, the South American survey has identified a number of potential agents that have the ability to exert significant damage on the plant both spatially and temporally across its native range. Studies to clarify which moth plant species are present in New Zealand and South America, and to determine the efficacy and host specificity of the diseases and invertebrates found during surveys are needed and are currently underway. If the host ranges of these potential agents are shown to be specific to the Asclepiadoideae sub family, then prospects for developing an effective biological control programme against moth plant in New Zealand would appear to be good.

\section{ACKNOWLEDGEMENTS}

The authors would like to thank a national collective of regional councils and Department of Conservation for providing the funding for this project, Lynley Hayes for programme management, Paula Wilkie and Stephanie Parkes for technical assistance and Dr Francisco Ochoa-Corona for his work on plant virus detection.

\section{REFERENCES}

Brotero FA 1817. Description of a new genus of plants named Araujia, and of a new species of Passiflora. Transactions of the Linnaean Society of London 12: 62-75.

Craw J 1999. Invasive weeds - setting new research priorities. In: Pearson C ed. Protect (Winter Issue). The New Zealand Biosecurity Institute Inc., Auckland, New Zealand. Pp. 4-7.

Esler AE 2004. Wild Plants in Auckland. Auckland University Press, Auckland, New Zealand. 218 p.

Esler AE 1988. Naturalisation of plants in urban Auckland. DSIR, Wellington, New Zealand. $196 \mathrm{p}$.

Forster PI, Bruyns PV 1992. Clarification of synonymy for the common moth-vine Araujia sericifera (Asclepiadaceae). Taxon 41: 746-749.

Fournier E 1885. Asclepiadaceae. In: Martius C ed. Flora Brasiliensis 6(4). Fleischer, Leipzig, Germany. Pp. 191-331.

Meyer T 1944. Asclepiadaceae. In: Descole H ed. Genera et species plantarum argentinarum. Instituto Miguel Lillo, Tucuman, Argentina. Pp. 3-273.

Roy B, Popay I, Champion P, James T, Rahman A 2004. An illustrated guide to common weeds of New Zealand. Second Edition. New Zealand Plant Protection Society, Lincoln, New Zealand. 314 pp.

Waipara NW 2004. The potential of Araujia Mosaic Virus (AjMV) as a biological control agent against moth plant, Araujia sericifera, in New Zealand. Landcare Research Contract Report LC0304/154. Landcare Research, Lincoln, New Zealand. 21 pp.

Waipara NW, Smith LA, Gianotti AF, Wilkie JP, Winks CJ, McKenzie EHC 2005. A survey of fungal plant pathogens associated with weed infestations of barberry (Berberis spp.) in New Zealand and their biocontrol potential. Australasian Plant Pathology 34: 369-376.

Webb CJ, Sykes WR, Garnock-Jones PJ 1988. Flora of New Zealand. Volume IV. Naturalised Pteridophytes, Gymnosperms, Dicotyledons. DSIR, Christchurch, New Zealand.

Winks CJ, Fowler SV 2000. Prospects for biological control of moth plant, Araujia sericifera (Asclepiadaceae). Landcare Research Contract Report LC9900/100. Landcare Research, Lincoln, New Zealand. 18 pp.

Winks CJ, Waipara NW, Gianotti AF 2004. Invertebrates and fungi associated with moth plant, Araujia sericifera, in New Zealand. Landcare Research Contract Report LC0405/009. Landcare Research, Lincoln, New Zealand. 26 pp. 